\title{
Urban Planning in Libya
}

\author{
By S. K. Kezeiri ${ }^{1}$
}

\begin{abstract}
Libya is one of the few countries in the Middle East to have a full coverage of Urban Plans and two generations of Master and Layout Plans have been provided by foreign consultants. The aim of urban planning in Libya is to provide urban amenities and infrastructures to all towns large or small and this article reviews how this has developed.
\end{abstract}

\section{Introduction}

Urban planning is a concept which specifically relates to physical land use planning at the city or town scale, and is concerned with the production of master plans with emphasis being placed on zonation of land in order to achieve a more rational pattern of future development including policies for redevelopment or conservation of existing structures (Clark 1980, 155). It has been variously described as 'the art and science of ordering the use of land and siting of buildings and communication routes so as to secure the maximum practicable degree of economy, convenience and beauty' (Keeble 1969).

In general, the accelerating process of urbanisation, the worst excesses of industrial societies and the explosion in population growth and car ownership, have all contributed towards a heightened awareness and ultimate acceptance of the need for the introduction of some form of regulation regarding the distribution of land between competing uses (Ratcliffe 1981, 13). In the case of Libya the need to plan stems from several factors.

Firstly, the total population of Libya in 1954 was little over one million people and since then the population has increased nearly three times. Between 1964 and 1973 the average annual growth exceeded $4 \%$ and it is estimated that the total population in 1980 was three million. Half of the population lives in Benghazi and Tripoli, with Tripoli having one million and Benghazi half a million (El Mehdawi et al. 1982, 68, 71). The total population of the country is expected to reach between a high of seven million and a low of five and a half million by the year 2000 , the proportion of this population residing in towns with 20,000 or more people is expected to rise to between $67 \%$ and $74 \%$ over the same period (El Shakhs 1975, 373). If such projections hold, this will result in tripling or quadrupling Libya's urban population over the next 17 years. All this means that the government must plan for the increasing population, providing schools, hospitals, houses, employment opportunities and leisure amenities by means of urban planning.

Secondly, by traditional measurements, Libya is already one of the most urbanised of the developing nations. Half of its total population of two and a quarter million in 1973 lived in settlements with 20,000 population size or over (Department of Census and Statistics 1977). According to the 1973 Census, Libya's population increased at an average annual rate of $4.2 \%$ between 1964 and 1973, substantial immigration of foreign labour occurred during this period, while rapid population increase formed the base for rapid urban growth (Blake 1979, 99). Moreover, comparison of 1966 and 1973 population revealed an astonishing average annual urban growth rate of $16 \%$ (El Shakhs 1975, 373). Figure 1 shows urban centres.in Libya in 1980.

Thirdly, the dramatic economic changes in Libya over the last two decades have increased the polarisation of population concentration in Tripoli and Benghazi. Oil revenues were dispersed through the urban system, especially into the big cities. The tide of migration from the rural areas into the two big cities is undoubtedly a reflection of rapidly changing

${ }^{1}$ Department of Geography, University of Durham 


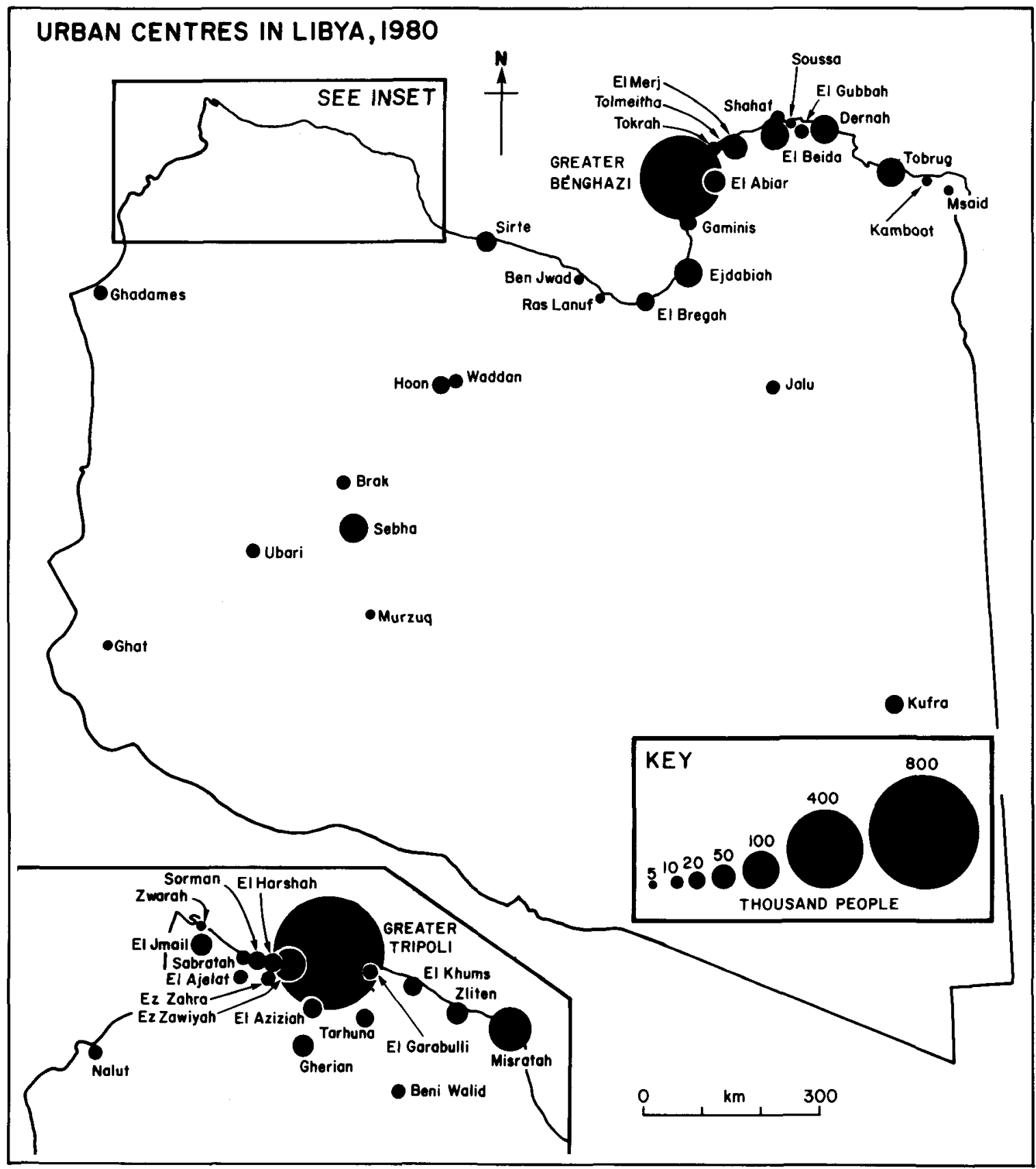

Figure 1. Urban centres in Libya, 1980.

economic conditions. Uncontrolled growth of these two centres has created severe imbalance in population distribution among different regions. The government is committed to reduce inequalities between regions and has tried to offset this high degree of spatial imbalance by channelling oil revenues into extensive infrastructure construction (Kezeiri 1982, 357, 58). In short, the benefits of oil revenues were to be taken to the people in the form of improved urban amenities and modern housing and services in towns of all sizes.

Libya is currently undergoing profound economic and social changes. The pressures resulting from these changes, both exogenous and endogenous, have succeeded in influencing 
the development decisions and policies adopted by the government (Yachiyo Engineering et al. 1980). Large scale government projects which have been initiated have channelled oil revenues into extensive infrastructural construction and socio-economic development programmes aimed at diversifying the economy, redressing regional population and income imbalance and curbing the alarming trend towards further primate city growth and congestion in the main cities of Tripoli and Benghazi.

A major aspect of government intervention is in the commissioning of a series of physical master and layout plans for all settlements in the country, urban or rural, large or small. Although many Middle Eastern cities and towns, specially the small towns, have been generally neglected from the planning point of view, Libya is one of the exceptions.

\section{The Roots of Town Planning}

The roots of town planning in Libya go back to the Italian era. Libyan towns had no master plans of any kind before the Italian occupation (1911). The Turkish Administration (15511911) left the built-up areas of the towns to expand without any proper planning. Four Italian Master Plans were prepared for Tripoli, Benghazi, Dernah and Misurata. Many Layout Plans were prepared for villages and much attention was given to the village as part of their colonisation programme. For the first time modern European planning ideas were applied in Libya such as the creation of 'Citta giardina' or the Garden City. Towns began to witness a new era of modern Italian urbanisation which has had a profound effect upon its morphology. Parts of the old towns were demolished to give way to wider streets or new buildings. New residential areas were built, new style of houses, villas and apartments for Italian officials and their families also improved the water supplies and sewerage systems in the main towns (Khuga 1969). This was for the benefit of their population, not for the Libyans. The existence of the old towns 'medina' and the modern extensions resulting in a striking juxtaposition of urban styles and the creation of 'dual cities' phenomenon with two separate cultures.

\section{Urban Planning before 1970}

The first town in Libya to have a master plan after independence was the small town of El-Marj. The old town was devastated by an earthquake in February 1963. Five months later, the government established the Barca Reconstruction Organisation as an independent body to locate the new town of El-Marj and to supervise the construction. The BRO commissioned the American company Lublin McGaughy Architects and Consulting Engineers to survey, located and design the new town. They instructed the planners to incorporate a number of concepts in the new town which were fundamentally western in origin, such as detached houses with front gardens wherever possible, neighbourhood centres with a range of facilities, and a grid network of wide roads. Thus the company designed the town on the concept of the 'Modern Town' or the 'Garden City' which is based on the theory developed by E. Howard in the nineteenth century (Lublin McGaughy 1964 and Asadi 1975).

The small market centre of El-Beida with 12,591 inhabitants in 1964, was chosen to be the capital of Libya in 1964 and so it was the second town to have a modern Master Plan. The Federal Government established Beida Project Committee to supervise the construction and the development of the town. In 1966 Doxiadis Associates prepared the Master Programme and Plan for El-Beida, providing for a city of 50,000 inhabitants in a first phase and a future extension for a possible 100,000 inhabitants. The development of E1-Beida since this period took place within the broad guidelines set out by the Doxiadis Plan (Doxiadis 1966 and 1979). The government was satisfied by the two previous Master Plans and obviously with oil money flowing abundantly, the Ministry of Planning and Development initiated in March 1966 an extensive urban planning programme with two aims; to regulate urban expansion and to make the benefits of the country's new found wealth accessible to as many citizens as possible (Blake 1979). 


\section{S. K. KEZEIRI}

The government awarded four separate contracts to four western consultants for the preparation of a comprehensive planning programme. In addition to aerial photographs and maps, the programme required inventory reports of existing conditions including resources, population, land use, settlement, community facilities, economy and transportation investigations. This information supplemented by additional field work and analysis was collected not only to serve as a reference for the existing conditions of the country but also as a basis for the preparation of Master Plans and Layout Plans.

Consultants were therefore allocated certain areas as follows: Firstly - Doxiadis Associates carried out the study of Eastern Muhafadat (excluding Benghazi, El-Beida and El-Marj). Nine towns and 65 smaller settlements were prepared by Master Plans and Layout Plans (Doxiadis 1968); secondly - McGaughy, Marshall, McMillian \& Lucan (UK) carried out the study for the Muhafadat of El Khums and Misurata. Seven Master Plans and 25 Layout Plans were prepared by them (McGaughy et al. 1968); thirdly-Architectural Planning Partnership Ltd of Denmark executed the study for the Muhafadat Ez-Zawiyah and Gebel Gharbi. The work carried out by Albert Speer, a German company under the aegis of APP. Eight Master Plans and 32 Layout Plans were prepared (Architectural Planning 1969); fourthly - Whiting Associates International (UK) prepared Master Plans for three cities i.e. Tripoli, Benghazi and Sebha, as well as 26 Layout Plans for the Southern Muhafadat (Whiting 1967, 1969-1970).

By 1970, the four consultants prepared 29 Master Plans and 148 Layout Plans and covered the whole country by inventory reports which still provide valuable information on the urban scene in Libya. The planning horizon for the Master Plans and Layout Plans was extended until 1988. The companies also prepared short-term programmes for implementing the Plans for the five-year period, April 1968 to April 1973, and April 1973 to April 1978.

Each report of each settlement outlines briefly the present structure of the town or village and examines the future pattern of the economic base, the demographic evolution, employment and income distribution, and defines the existing problems both quantitatively and qualitatively, and estimates the needs for each settlement which define the framework for the Master Plan and the Layout Plan and the five-year period programme. Conservation of the old parts of towns was taken into consideration and the Plans introduced some important ideas regarding the old cities cores or medinas in Benghazi, Tripoli and Sebha. Although the physical Master Plans themselves were instrumental in bringing modern services such as sewerage, fresh water and electricity to the small towns and attempts were made to rationalise road systems and urban land use and to build modern housing, however, they have certain weaknesses (Blake 1979).

One is that the drawing up of these plans is characterised by an absence of citizens' participation in each municipality as it is essentially the work of the Central government. Blake has rightly drawn out attention to some of these weaknesses as follows: firstly, plans failed to examine the different growth potential of towns in a national context and to give positive encouragement to those favourably located; secondly, 20 years was probably too long as a time span considering the detailed nature of the plans and the spectacular rate of change brought about by the oil revenues; thirdly, when the plans were devised, industrial development on a large scale was not foreseen while the emphasis on heavy industry is relatively recent; finally, Master Plans have largely overlooked the possibility of adapting traditional urban styles to the needs of the modern world (Blake 1979).

In addition, the plans have mostly become out-of-date since in many instances the development areas have been wholly built-up or used adversely to the provision of these plans. By and large the plans did not anticipate such a rapid urban development as observed at present in the urban centres of Libya and therefore they did not take into account decisions which have been taken after their elaboration, i.e. the construction of roads, railways, location of new industries, development of agriculture, development of health education, housing and 
the development of airports and ports etc. Therefore the government found it necessary to elaborate new Master and Layout Plans for all settlements in the country up to the year 2000. It is important to notice that the plans were all similar.

\section{Urban Planning after 1970}

The increasing awareness of the government of the importance of the spatial dimensions in the development process and the need for achieving greater urban-rural balance and interregional equity leads it to establish the Spatial Planning Department in the Ministry of Planning in the early 1970s, and in 1973 to commissioning Italconsult to study all Libyan settlement. Three years later the consultant produced the Final Report of the Settlement Pattern Study composed of eight separate volumes and two sets of full scale maps. The first volume contains a summary of the study and a detailed evaluation of Regional Development in terms of the existing conditions, current government policies and recommended settlement development strategies and infrastructure requirements for the year 2000. The five Regional Report Volumes are concerned with the six Planning Regions into which Libya has been divided, namely, Benghazi, Tripoli, Gherian, El Khalij, Calanscio and Sebha Region. As far as Town Planning is concerned, the Reports also contained 36 detailed City Profiles with population and infrastructure forecasts elaborated at five-yearly intervals to the year 2000 . The other two volumes are concerned with Evaluation of Settlements and Appendix. (Italconsult 1977).

Italconsult's study is very important; for the first time in Libya, the development of settlements is seen at regional and national level. Past settlement studies as we have seen, have been mainly of a city or town planning nature, concerned basically with local socioeconomic analysis and land development possibilities. However, Italconsult study is of a different nature. It also aims to distinguish from among all settlements those to be up-graded or down-graded to orient priorities in future economic technical and social infrastructure programmes (Italconsult 1977).

The late 1970s and the beginning of the 1980s saw a new generation of Master Plans and Layout Plans prepared by consultancy companies and guided by three important references: firstly the work of Italconsult on settlement patterns. Secondly, the National Physical Perspective Plan, which was prepared by the government with the United Nation's technical team (Secretariat of Municipalities et al. 1979) and lastly by the 'Term of Reference for Regional and Master Plans' which was prepared by the Secretariat of Municipalities (Secretariat of Municipalities 1977).

Since 1979, the Libyan authorities have started regional planning for the economic and social development of the country to the year 2000. A national framework was set up for short-term five-year and long-term, 20-year, plans and regional plans were elaborated based on four areas, Benghazi and the Jabel el Akhdar, Tripoli and the western coastal districts, Sebha, including much of what was the Fezzan and El-Khalij extended from the Gulf of Sirte to Kufra (McLachlan 1982). Within this regional planning context, Master Plans and Layout Plans were formulated and designed up to the year 2000. Four foreign planning groups were invited to prepare inventories of existing conditions within each region. Series of reports prepared by each consultant covering the development of each region up to the year 2000, including preliminary and final Regional, Master and Layout Plans for certain settlements in each region. In addition each consultant is responsible for delivering associated aerial photography and maps. Each Report of Master and Layout plan analyses existing conditions, evaluates resources and constraints, sets out forecasts on population and employment; develop a programme for social and technical infrastructure, all expressed spatially in the physical Master or Layout Plans.

The government commissioned Doxiadis Associations International (for the second time) to undertake the development plan for the Benghazi Region and to prepare 11 Master Plans 
and 55 Layout Plans (Doxiadis 1980). For the Tripoli Region, Polservice was commissioned to prepare 33 Master Plans and 46 Layout Plans (Polservice 1980). Speerplan of Frankfurt, West Germany has undertaken the study, planning and mapping of all settlements in El-Khalij Region with the cooperation of Finnmap Cy of Helsinki (Speer Plan 1980). Finnmap also carried out work in the Sebha Region which began rather later than elsewhere (Finnmap 1981) and the preliminary regional strategy for development was not presented to the Libyan authorities until May 1982 (McLachlan 1982). The government also commissioned seven separate consultants to prepare Master Plans for seven new towns at Assarir, Gaser Ahmed, Ras Lanuf, El-Bregah, El-Gwarshah, Hrawah and Az Zintan.

\section{Conclusion}

In conclusion, it has been the aim of urban planning in Libya as part of the national economic and social planning, to try to reduce inequalities between towns by providing urban amenities and infrastructure construction for Libya's growing population. Great opportunities have existed for a range of dynamic urban planning policies as a result of the increase in the oil revenues. Enormous government efforts have been made. Before 1973 government intervention was largely confined to the commissioning of a series of physical Master and Layout Plans and for a policy of equitable distribution of services and development benefits throughout the country and every citizen was to be provided with adequate services in the fields of education, health, housing and transport. Integrated planning for the development of Libya's network of urban centres was given serious consideration after 1973. This can be seen in the government's attempt to locate manufacturing industries in a large number of towns, adopting growth pole policies and the development of the southern regions.

Urban planning has attempted to respond through a series of control mechanisms to urban growth which has occurred. Urban planning processes can be found, not only in Master and Layout Plans provided, but also in the range of actions which were designed to improve the physical, social and economic fabric of towns and cities in the country. Although some points of weakness were shown in the 1960s Master Plans, it is as yet too early for any assessments regarding the 1970s Master Plans. However, if the Master and Layout Plans are to be brought into being as a built environment, manpower, money and time are required.

\section{Acknowledgements}

The author wishes to acknowledge the assistance given to him during his research into urban development in Libya. In particular the many Libyan officials who gave their time and help during fieldwork in Libya are acknowledged. It would be appropriate to give special thanks to Mr Milud Helmi of the Urban Planning Department, Mr Moftah Ramadan Awn of the Spatial Planning Department, Mr Ibrahim Wafa of the Secretariat of Utilities and Mr Ali Suleiman of Eternit Company. The author also would like to thank Dr R. I. Lawless and Dr G. H. Blake for their various comments.

\section{Bibliography}

Architectural Planning Partnership. 1969. Gherian Master Plan 1988. Report prepared for the Government of Libya. Tripoli.

Asadi, Fawzi. 1975. The spatial structure of the New Town of El-Marj and its Adaptability to the Libyan Culture. Unpublished paper presented to The First Geographical Conference Faculty of Arts. Benghazi.

Blake, G. H. 1979. Urbanisation and Development Planning in Libya. In R. A. Obudho and Salah El-Skakhs (eds.). Development of Urban Systems in Africa. New York, Praeger.

Clark, B. D. 1980. Urban Planning: Perspective and Problem. In G. H. Blake and R. I. Lawless (eds.). The Changing Middle Eastern City. London, Croom Helm.

Department of Census and Statistics. 1977. The Results of the 1973 Census of Population. Tripoli, Libya.

Doxiadis Associates. 1966. Beida: Final Master Programme and Plan. Prepared for Beida Project Committee, Benghazi.

Doxiadis Associates, 1968. Master Plans and Layout Plans for the Eastern Region. Development Reports to the Government of Libya - up to 40 volumes in Arabic and English - Benghazi. 


\section{URBAN PLANNING IN LIBYA}

Doxiadis Associates International. 1979. Benghazi Region - Beida Subregion, Baladiyah of Beida Master Plan. Report 3.2.

Doxiadis Associates International. 1980. Existing Conditions in the Benghazi Region. Athens.

E1 Mehdawi, M. and Clarke, J. I. 1982. Population redistribution in Libya. In J. I. Clarke and L. A. Kosinksi (eds.). Redistribution of Population in Africa. London, Heinemann.

E1 Shakhs, S. 1975. Urbanisation and Spatial Development in Libya. Pan-African Journal 8, 4: 371-386.

Finnmap. 1981. Existing conditions in Sebha Region. Helsinki.

Italconsult, 1976. Libya Settlement Pattern Study. Rome. 8 Vols.

Keeble, L. 1969. Principles and practice of town and country planning. Estates Gazette.

Kezeiri, S. K. 1982. Re-structuring the Urban System in Libya. In E. G. H. Joffe and K. S. McLachlan, Social and Economic Development of Libya. London, MENAS.

Khuga, M. 1969. The Growth and Function of Tripoli. Unpublished PhD Thesis, Geography Department, Durham University, Durham.

Lublin McGaughy, 1964. Planning Report for the New Town El-Marj. Prepared for Barca Reconstruction Organization, Benghazi.

McGaughy, Marshall, McMillan and Luca. 1968. Master Plans and Layout Plans for the Muhafadat of ElKhums and Misurata. Reports to the Government of Libya up to 15 volumes. Tripoli.

McLachlan, K. S. 1982. Planning for change in Fezzan. Libyan Studies 13.

Polservice. 1980. Existing Conditions and Evaluation of Development Potentials. Tripoli Region, Warsaw.

Ratcliffe, J. 1981. An Introduction to Town and Country Planning. London, Hutchinson.

Secretariat of Municipalities. 1977. Terms of Reference for Regional and Master Plans for the Socialist People Libyan Arab Jamahiriya. Tripoli.

Secretariat of Municipalities and Secretariat of Planning and United Nations Technical Co-operation Physical Planning Project. 1979. National Physical Perspective Plans, 1981-2000. Tripoli.

Speerplan. 1980. Existing Conditions in El-Khalij Region. Frankfurt.

Whiting Associates International. 1967. Benghazi Master Plan Final Report. Benghazi.

Whiting Associates International. 1969. Tripoli Master Plan Final Report. Tripoli.

Whiting Associates International. 1970. Southern Region Final Report. Tripoli.

Yachiyo Engineering and Kisho Kurokawa Architect. 1980. 1981 Planning, Designing and Supervising of Assarir New Town. Four volume report submitted to the Higher Committee of the Executive Authority of the Project of Planning and Construction of Assarir New Town. Benghazi - Tokyo. 